\title{
METODE PEMBELAJARAN KOMBINASI (SELF DAN PEER ASSESSMENT) EFEKTIF MENINGKATKAN KETERAMPILAN MAHASISWA DI LABORATORIUM KLINIK
}

\author{
Dilistia Lestari ${ }^{1)}$, Hadi Susiarno ${ }^{2)}$, Hadyana Sukandar ${ }^{3)}$ \\ ${ }^{1)}$ Program Studi Magister Kebidanan FK Unpad \\ ${ }^{2)}$ Departemen Obstetri dan Gynekologi FK Unpad \\ ${ }^{3)}$ Departemen Ilmu Kesehatan Masyarakat FK Unpad \\ E-mail: dilistialestari@ymail.com
}

\begin{abstract}
Midwife profession must have good competence because it has an impact in improving the quality of health service. Survey of Midwifery Diploma III Institutions. Midwife competencies that match work requirements are only 15\%. To improve the competence of midwives, the laboratory learning process must be carried out properly according to standards. The combination of self and peer assessment methods is learning to get feedback, encourage students to be more active, independent, responsible, practice evaluation skills and encourage deep learning to maximize the achievement of competencies. The purpose of this study is to analyze the effect of a combination of self and peer assessmentlearning methods on D III Midwifery student competencies. This research is a quantitative study with a quasi-experimental pre-post test design. The study population was all students of D III Midwifery Semester III with a total of 75 people. Sampling uses simple random sampling technique which is divided into three groups for self assessment, peer assessment and a combination of self and peer assessmentmethods, each group totaling 25 people. The research instrument uses a checklist. The statistical test used is Kruskal_Wallis. the results showed that the combination of self and peer assessmentmethods showed more increases by $13.2 \%(p<0.001)$ compared to the peer assessment method 10.6\% $(p<0.001)$ and the self assessment method 8.3\% $(p<0.001)$. The conclusion of this study isthe application of the self and peer assessmentmethods can have a significant influence on the competence of D III Midwifery students.
\end{abstract}

Keyword : Competence; learning method; self andpeer assessment.

Cara mengutip: Lestari, Dilistia., Susiarno, Hadi \& Sukandar, Hadyana. (2020). Metode Pembelajaran Kombinasi (Self dan Peer Assessment) Efektif Meningkatkan Keterampilan Mahasiswa di Laboratorium Klinik. Care:Jurnal Ilmiab Ilmu Kesehatan, 8(1), 48-61 


\begin{abstract}
ABSTRAK
Profesi Bidan dituntut memiliki kompetensi yang baik karena berdampak pada kualitas pelayanan. Kajian terhadap institusi DIII Kebidanan kompetensi lulusan bidan yang sesuai kebutuhan kerja hanya 15\%. Untuk meningkatkan kompetensi diperlukan proses pembelajaran laboratorium yang baik selama pendidikan. Metode kombinasi self dan peer assessment merupakan inovasi pembelajaran untuk memperoleh umpan balik (feed back), mendorong siswa lebih aktif, mandiri, tanggungjawab, melatih evaluation skill serta belajar lebih mendalam (deep learning) untuk memaksimalkan pencapaian kompetensi.Tujuan penelitian ini menganalisis pengaruh metode pembelajaran kombinasi self dan peer assessment terhadap kompetensi mahasiswa DIII Kebidanan. Penelitian ini adalah penelitian kuantitatif dengan rancangan kuasi eksperimen pre-post test design. Populasi penelitian yaitu seluruh mahasiswa Prodi DIII Kebidanan Semester III sebanyak 75 orang.Pengambilan sampel menggunakan teknik simple random sampling yang dibagi kedalam tiga kelompok untuk metode self, peer dan kombinasiself dan peer assessment, masing masing kelompok sejumlah 25 orang. Instrumen penelitian menggunakan daftar tilik. Uji statistik menggunakan Kruskal Wallis hasil penelitian menujukan terdapat kenaikan lebih besar pada metode kombinasi self dan peer assessment sebesar 13,2\% ( $<<0,001)$ dibandingkan metode peer assessment 10,6\% $(\mathrm{p}<0,001)$ dan metode self assessment $8,3 \%(\mathrm{p}<0,001)$. Penerapan metode kombinasi self dan peer assessment dapat memberikan pengaruh yang bermakna terhadap kompetensi mahasiswa D III Kebidanan.
\end{abstract}

Kata Kunci : Kompetensi; metode pembelajaran; kombinasiself dan peer assessment.

\section{PENDAHULUAN}

Angka kematian ibu (AKI), bayi (AKB) dan anak balita di Indonesia masih cukup tinggi.Menurut Survey Demografi Kesehatan Indonesia (SDKI) Tahun 2012 AKI dan AKBmenunjukkan angka 359/100.000 Kelahiran Hidup (KH) dan AKB 22,23/ 1000 KH. Salah satu tujuan pembangunan berkelanjutanSustainable Development Goals (SDGs) 2015-2030 yaitu berkomitment untuk menurutkan AKI dan AKB di Indonesia.

Hasil kajian survey kualitas pendidikan kebidanan di Indonesia tahun 2011-2012 dan kajian implementasi kurikulum D III
Kebidanan Tahun 2013 menunjukkan terdapat $88,64 \%$ persalinan ditolong oleh tenaga kesehatan dan $75 \%$ persalianan ditolong oleh bidan. Berdasarkan kajian terhadap institusi pendidikan DIII kebidanan di daerah binaan yaitu Papua, Papua Barat, Sulawesi Selatan, Jawa Barat, dan Banten sebanyak 18 institusi kebidanan (9 Poltekkes dan 9 Non Poltekkes) yang mewakili institusi pendidikan kebidanan tersebut dikemukakan kualitas dan kompetensi tenaga kesehatan belum sepenuhnya sesuai dengan standar pelayanan dan belum dapat memberikan kontribusi maksimal untuk menjalankan peran 
strategisnya karena tingkat dan relevansi kompetensinya belum sesuai. Selain itu,kompetensi lulusan pendidikan bidan yang sesuai kebutuhan kerja hanya $15 \%$.

Kompetensi lulusan bidan yang masih belum sesuai dengan kebutuhan masyarakatakan berdampak langsung pada kualitas pelayanan yang diberikan, salah satunya dalam memberikan asuhan bayi baru lahir. Sebanyak $67,8 \%$ bayi lahir melalui pertolongan persalinan oleh bidan. Dengan demikian kompetensi bidan dalam asuhan bayi baru lahir menjadi salah satu faktor penting untuk meningkatkan kesehatan bayi yang dilahirkan. Menurut Suryadi, 2008 terdapat tiga komponen utama yang menentukan keberhasilanpencapaian kompetensi diantaranya konten materi keterampilannya, metode atau strategi yang diterapkan dalam pembelajaran, dan peserta didiknya.

Metode pembelajaran laboratorium mempunyai peran dalam meningkatkan kompetensi dan kepercayaan diri mahasiswa dalam berlatih keterampilan (Dornan, 2011). Salah satu permasalahan yang dijumpai dalam pembelajaran praktek di laboratorium klinik diantaranya adalah metode pembelajaran yang kurang melibatkan peran aktif mahasiswa, rasio dosen dan mahasiswa yang tidak seimbang sehingga kesempatan mahasiswa untuk mendapatkan umpan balik(feed back) dalam pembelajaran kurang maksimal. Untuk itu, salah satu upaya yang dapat dikukan adalah dengan menerapkan metode pembelajaran inovatif yang melibatkan peran aktif dari mahasiswa.

Self dan peer assessment membantu peserta didik untuk mengembangkan kemampuan membuat keputusan yang merupakan salah satu keterampilan yang dibutuhkan untuk belajar dan bekerja nantinya. Selain itu, dari penerapan metode peer assessment, peserta didik dapat membangun pengetahuan dari umpan balik yang diberikan oleh peserta didik lainnya (Zurharman, 2007). Dengan mengetahui kelebihan dan kelemahan dirinya dari hasil umpan balik maka siswa dapat memilih teknik belajar yang tepat untuk meningkatkan kemahiran dalam melakukan asuhan kebidanan khususnya pemeriksaan fisik pada bayi baru lahir. Bidan sebagai pelaksana kesehatan dituntut untuk mampu melakukan pemeriksaan fisik pada bayi baru lahirsesuai dengan standar kompetensi bidan, maka diperlukan suatu metode 
pembelajaran di laboratorium keterampilan klinik (skills lab) yang dapat memfasilitasi mahasiswa untuk belajar sehingga tujuan pembelajaran yang diharapkan dapat tercapai.

\section{METODE PENELITIAN}

Penelitian ini menggunakan metode kuantitatif, untuk menjawab pengaruh variabel bebas terhadap variabel terikat. Variabel bebas adalah penerapan metode pembelajaran (metode self assessment, peerassessment dan kombinasi self dan peer assessment) variabel terikat adalah kompetensi pemeriksaan fisik bayi baru lahir. Jenis penelitian kuasi eksperimental dengan rancanganpre test-post test control group design. Populasi penelitian yaitu seluruh mahasiswa tingkat II Semester III Tahun Akademik 2018/2019 sejumah 75 orang.Pengambilan sampel menggunakan teknik simple random sampling dengan tahapan : 1) Sampel disusun berdasarkan predikat hasil belajar/Indeks Prestasi Komulatif (IPK) 2) Setiap sampel di kelompokkan dan di random untuk ke tiga metode pembelajaran self assessment, peer assessment dan kombinasi self dan peer assessment3) Teknik random dilakukan dengan cara menngundi nama-nama responden.Data yang dikumpulkan berupa data sekunder yaitu prestasi akademik (nilai IPK) yang di peroleh dari bagian akademik dan data primer yaitu hasil penilaian kompetensi pemeriksaan fisik bayi baru lahir dangaya belajar mahasiswa.

Instrumen yang digunakan dalam penelitian ini berupa daftar tilik kompetensi pemeriksaan fisik bayi baru lahir dalam buku panduan Asuhan Neonatus dan Bayi Baru Lahir Kementrian Kesehatan yang digunakan dan sudah terstandar. Tahap pengumpulan data pada penelitian ini :pertama dilakukan pengukuran awal (pre test) pada seluruh mahasiswa. Kedua,penerapan metode pembelajaran dengan membagi kelompok 1 diberikan perlakuan metode self assessment, kelompok 2 diberikan perlakuan metode peer assessment, dan kelompok 3 diberikan perlakuan metode kombinasiself dan peer assessment. Ketiga, setelah perlakuan dilakukan pengukuran akhir (post test).

Sebelum dilakukan uji statistik terlebih dahulu dilakukan uji homogenitas dengan nilai $\mathrm{p}>0,05$ dapat disimpulkan layak untuk diperbandingkan. Uji statistik menggunakan Kruskal_Wallis hasil penelitian menujukan terdapat kenaikan lebih besar pada metode kombinasi self dan peer assessment sebesar 13,2\% ( $\mathrm{p}<$ 0,001) dibandingkan metode peer assessment 
$10,6 \%(\mathrm{p}<0,001)$ dan metode self assessment

$8,3 \%(\mathrm{p}<0,001)$

Penelitian ini sudah mendapat

pembebasan etik dengan Nomor
1351/UN6.KEP/EC/2018 dari Komisi

Etik Penelitian Universitas Padjadjaran Bandung.

\section{HASIL}

Tabel 1. Karakteristik (IPK dan Gaya Belajar) Pada Ketiga Kelompok Penelitian

\begin{tabular}{|c|c|c|c|c|}
\hline \multirow[b]{2}{*}{ Variabel } & \multicolumn{3}{|c|}{ Metode Pembelajaran } & \multirow[b]{2}{*}{ Nilai $p$} \\
\hline & $\begin{array}{c}\text { Kombinasiself dan } \\
\text { peer Assessment } \\
(\mathrm{n}=25)\end{array}$ & $\begin{array}{c}\text { Peer } \\
\text { Assessment } \\
(\mathrm{n}=25)\end{array}$ & $\begin{array}{c}\text { Self } \\
\text { Assessment } \\
(\mathrm{n}=25)\end{array}$ & \\
\hline 1. IPK & & & & $0,331 *$ \\
\hline$\overline{\mathrm{x}}(\mathrm{SD})$ & $3,22(0,17)$ & $3,16(0,20)$ & $3,15(0,16)$ & \\
\hline Median & 3,2 & 3,18 & 3,18 & \\
\hline Rentang & $2,73-3,51$ & $2,75-3,51$ & $2,75-3,51$ & \\
\hline $\begin{array}{l}\text { Cumlaude } \\
(3,51-4,00)\end{array}$ & 3 & 3 & 1 & \\
\hline $\begin{array}{l}\text { Sangat Memuaskan } \\
(2,76-3,50)\end{array}$ & 21 & 20 & 22 & \\
\hline $\begin{array}{l}\text { Memuaskan } \\
(2,75-2,00)\end{array}$ & 1 & 2 & 2 & \\
\hline 2. Gaya Belajar & & & & $0,618^{* *}$ \\
\hline Mandiri & 12 & 12 & 15 & \\
\hline Kelompok & 13 & 13 & 10 & \\
\hline
\end{tabular}

Ket : *) Uji Mann-Whitney ; **) Uji Chi Kuadrat

Berdasarkan Tabel 1 diketahui tidak bermakna $(p>0,05)$, dengan karakteristik IPK dan Gaya Belajar pada homogenits karakteristik ini maka layak ketiga kelompok penelitian secara statistik diperbandingkan.

Tabel 2. Perbandingan Kompetensi Pemeriksaan Fisik Bayi Baru Lahir dari Ketiga Kelompok Perlakuan

\begin{tabular}{|c|c|c|c|c|c|}
\hline \multirow{2}{*}{\multicolumn{2}{|c|}{ Kompetensi }} & \multicolumn{3}{|c|}{ Metode Pembelajaran } & \multirow[b]{2}{*}{ Nilai $\mathrm{p}^{*}$} \\
\hline & & $\begin{array}{c}\text { Kombinasi self dan } \\
\text { peer Assessment } \\
(\mathrm{n}=25)\end{array}$ & $\begin{array}{c}\text { Peer } \\
\text { Assessment } \\
(\mathrm{n}=25)\end{array}$ & $\begin{array}{c}\text { Self } \\
\text { Assessment } \\
(\mathrm{n}=25)\end{array}$ & \\
\hline & $\begin{array}{l}\text { Pre Test } \\
\bar{x}(\mathrm{SD}) \\
\text { Median } \\
\text { Rentang }\end{array}$ & $\begin{array}{c}66,4(3,4) \\
68 \\
60-71\end{array}$ & $\begin{array}{c}65,0(3,9) \\
65 \\
60-70\end{array}$ & $\begin{array}{c}65,1(4,2) \\
65 \\
60-71\end{array}$ & 0,379 \\
\hline 2. & $\begin{array}{l}\text { Post Test } \\
\overline{\mathrm{x}}(\mathrm{SD}) \\
\text { Median } \\
\text { Rentang }\end{array}$ & $\begin{array}{c}75,1(1,5) \\
75 \\
71-77\end{array}$ & $\begin{array}{c}72,6(2,9) \\
73 \\
66-77\end{array}$ & $\begin{array}{c}72,0(3,2) \\
73 \\
65-77\end{array}$ & 0,001 \\
\hline 3. & $\begin{array}{l}\text { Perbandingan } * * \\
\text { Pre Test us Post Tes }\end{array}$ & $\mathrm{p}<0,001$ & $\mathrm{p}<0,001$ & $\mathrm{p}<0,001$ & \\
\hline
\end{tabular}

Ket : *) Uji Kruskal-Wallis **) Uji Wilcoxon 
Berdasarkan Tabel 2 menunjukkan kompetensi pemeriksaan fisik bayi baru lahir sebelum penerapan metode pembelajaran menunjukkan tidak ada perbedaan yang bermakna $(p>0,05)$, sedangkan pada pengamatan setelah penerapan metode pembelajaran menunjukkan terdapat perbedaan yang bermakna pada ketiga kelompok metode pembelajaran. Selanjutnya pada data post test dari hasil analisis lebih lanjut dengan uji Mann-Whitney terdapat perbedaan kompetensi yang bermakna antara metode kombinasiself dan peer assessment versus metode peer assessment $(\mathrm{p}=0,001)$ dan metode kombinasiself dan peer assessment versus metode self assessment $(\mathrm{p}=0,001)$, sedangkan antara metode peer assessment versus metode self assessment tidak menunjukkan perbedaan yang bermakna $(p=0,366)$.

Tabel 3. Perbandingan Kenaikan Kompetensi Pemeriksaan Fisik Bayi Baru Lahirdari Ketiga Kelompok Perlakuan

\begin{tabular}{|c|c|c|c|}
\hline \multirow[b]{2}{*}{ Kompetensi } & \multicolumn{3}{|c|}{ Metode Pembelajaran } \\
\hline & $\begin{array}{c}\text { KombinasiSelf dan } \\
\text { Peer Assessment } \\
(\mathrm{n}=25)\end{array}$ & $\begin{array}{c}\text { Peer Assessment } \\
\quad(\mathrm{n}=25)\end{array}$ & $\begin{array}{l}\text { Self Assessment } \\
\quad(\mathrm{n}=25)\end{array}$ \\
\hline 1. Kenaikan & & & \\
\hline $\bar{x}(\mathrm{SD})$ & $8,6(3,2)$ & $7,6(3,5)$ & $6,8(3,9)$ \\
\hline Median & 9 & 7 & 5 \\
\hline Rentang & $4-17$ & $2-16$ & $2-14$ \\
\hline 2. \% Naik (Median) & $13,2 \%$ & $10,6 \%$ & $8,3 \%$ \\
\hline
\end{tabular}

Berdasarkan Tabel 3 dapat di hitung persentase kenaikan kompetensi pemeriksaan fisik bayi baru lahir dari ketiga kelompok perlakuan, untuk kelompok metode self dan peer assessment besar kenaikan adalah 13,2\%, lebih besar dari kelompok metode peer assessment dengan besar kenaikan $10,6 \%$ dan kelompok metode self assessment dengan besar kenaikan 8,3\%.

\section{PEMBAHASAN}

Berdasarkan hasil penelitian yang dilaksanakan di Akademi Kebidanan Graha Husada Cirebon diperoleh hasil kompetensi pemeriksaan fisikbayi baru lahir sebelum penerapan metode pembelajaran menunjukkan tidak ada perbedaan yang bermakna $(p>0,05)$, sedangkan pada pengamatan setelah penerapan metode pembelajaran menunjukkan ada perbedaan yang bermakna pada ketiga kelompok metode 
pembelajaran. Selanjutnya pada data post test dari hasil analisis lebih lanjut dengan uji Mann Whitney terdapat perbedaan kompetensi antara metodeself dan peer assessment versus metode peer assessment dengan nilai $\mathrm{p}=0,001$, metode kombinasi self dan peer assessment versus metode self assessment dengan nilai $\mathrm{p}=0,001$ dan metode peer assessment versus metode self assessment dengan nilaip $=0,366$.

Terdapat peningkatan kompetensi pemeriksaan fisik bayi baru lahir pada ketiga metode pembelajaranself assessment, peer assessment, kombinasiself danpeer assessment dan persentase kenaikan kompetensi pemeriksaan fisik bayi baru lahir dari ketiga kelompok perlakuan. Untuk kelompok metode kombinasiself dan peer assessmentbesar kenaikan adalah 13,2\%, lebih besar dari kelompok metode peer assessment dengan besar kenaikan 10,6\% dan kelompok metode self assessment dengan besar kenaikan 8,3\%. Dari hasil penelitian terdapat pengaruh metode pembelajaran kombinasi peer dan self assessment dengan kompetensi pemeriksaan fisik bayi baru lahir $(p=0,001)$.

Salah satu area kompetensi bidan yang harus dikuasai adalah keterampilan klinik meliputi keterampilan dalam melakukan pengumpulan data, penegakan diagnosis melalui anamnesis, pemeriksaan fisik, pemeriksaan penunjang serta keterampilan lain dalam melakukan asuhan kebidanan. Berdasarkan hal tersebut, kewajiban institusi pendidikan untuk merancang kurikulum yang mengacu pada aspek keterampilan klinik serta menjamin para lulusannya mencapai kompetensi tersebut sesuai dengan tujuan pembelajaran.Penguasaan keterampilan merupakan elemen penting dari mutu professional lulusan pendidikan kebidanan yang merupakan bukti nyata tercapainya kompetensi.

Menurut Suryadi (2008) terdapat banyak faktor yang terlibat dalam suatu proses pembelajaran laboratorium keterampilan klinik salah satunya penerapan metode pembelajaran. Hal tersebut harus terlaksana secara baik agar proses pembelajaran dapat mencapai tujuan. Metode pembelajaran laboratorium mempunyai peran yang besar dalam meningkatkan kompetensi dan kepercayaan diri mahasiswa dalam berlatih keterampilan. (Alias, 2015)Penelitian ini mengembangkan suatu metode pembelajaran dengan melibatkan peran aktif siswa dalam proses evaluasi dan pembelajaran. 
Salah satu faktor penting dari perangkat pembelajaran adalah penilaian dan merupakan bagian yang tidak dapat dipisahkan dari proses pembelajaran. Penilaian formatif merupakan alternative penilaian yang dapat diterapkan dalam proses pembelajaran (Rochmiati, 2013) Metode pembelajaran yang dapat melibatkan siswa secara aktif diantaranya metodeself dan peer assessment (Bostock, 2000).

Self assessment (penilaian diri) merupakan suatu teknik penilaian dimanasiswa dalam proses pembelajaran berperan untuk menilai dirinya sendiri yang berkaitan dengan proses dan pencapaian hasil pembelajarannya.Metode self assesment dapat digunakan untuk mengukur kompetensi kognitif, afektif dan psikomotorik peserta didik itu sendiri.Padapelaksanaannya peserta didik dilibatkan dalam mengidentifikasi kriteria atau standar yang ingin dicapai dan diterapkan dalam proses belajar. Dengan kata lain penerapan self assessment dalam pembelajaran merupakan sebuah proses dimana pelajar memiliki tanggung jawab untuk menilai proses dan hasil belajarnya sendiri (Sally, 2005).

Self assesment merupakan faktor penting yang bersifat objektif dalam pencapaian prestasi dan hasil belajarsiswa sendiri.Brown (2005) menyatakan bahwa penerapan self assessmentmerupakancara yang efektif untuk mengembangkan belajar mandiri dan membantu dalam mengubah persepsi pembelajaran ke arah yang lebih baik, khususnya untuk pembelajaran keterampilan dan kinerja. Self assesment juga merupakan strategi yang baik dan sangat penting misalnya dalam strategi pedagogik karena dengan penilaian diri inilah siswa dapat memperoleh pengalaman balajar secara menyeluruh dan kompleks. Hal tersebut sejalan dengan pendapatSally (2005) bahwa penilaian diri tidak hanya penting karena menunjukkan kepada kita apa yang siswa tahu dan tidak tahu, tetapi juga memberikan umpan balik/refleksi atas pencapaian siswa (McMillan, 2008).

Penggunaan metode self assessment dalam pembelajaran sesuai dengan penelitian yang dilakukan oleh Ross JA tentang The reliability, validity, andutility of self assessment, bahwa penerapanselfassessment dalam pembelajaran dapat membantu siswa meningkatkan hasil belajar dan memperbaiki perilaku belajar siswa. Selanjutnya, McMillan (2005) dalam penelitiannya tentang student self assessment: the key tostronger student motivation and bigherachievement mendapatkan kesimpulan 
bahwa self assessment dapat didefinisikan sebagai keterlibatan siswa dalam menilai performance mereka sendiri secara objektifberdasarkan bukti dan kriteria yang sudah ditentukan yang bertujuan untuk meningkatkan kriteria capaian pembelajaran, hasil penelitian ini juga menegaskan bahwa self assessment berorientasi terhadap pencapaian tujuan, di mana yang menjadi fokusnya adalah pada peningkatan pengetahuan, pemahaman, dan keterampilan.

Berdasarkan hasil penelitian terjadi peningkatan kompetensi pada kelompok metode peer assessement. Penerapan peer assessment dalam proses pembelajaran merupakan proses dimana pelajar menilai hasil belajar teman atau pelajar lainnya yang berada se-level dalam subjek, tujuan, pembelajaran dan kelas yang sama. Karakteristik lain dari penerapan peerassessment adalah proses dimana anggota dari suatu tim saling melakukan assess, maka pemahaman tujuan dari proses pembelajaran harus dipahami siswa dengan baik. Peer assessment dapat dikatakan sebagai assessment alternative yang melibatkan siswa dan memberi kesempatan kepada siswa untuk mengemukakan pendpat (Kiliq, 2007).
Peer assesment melibatkan siswa berkolaborasi dan berbagi ide, pikiran dan pengamatan yang bertujuan untuk proses belajar yang lebih baik. Peerassesment memiliki peran penting dalam keberhasilan pencapaian kompetensi, dan dalam penerapannya diperlukan kepercayaan dan kerja sama antar siswa dalam kelompok pembelajaran. Sehingga penerapan peer assessment dapat digunakan untuk memaksimalkan kegiatan belajarnya khususnya dalam mengembangkan kemampuan kerjasama, mengkritisi proses dan hasil belajar orang lain dan dapat digunakan sebagai penilaian formatif. Menurut Orsmond (2004) salah satu kelebihan yang didapat dari penerapan metode self dan peer assessment yaitu perolehan umpan balik (feed back) dalam kegiatan pembelajaran. Menurut Weaver dalam Bedford (2007) umpan balik (feed back) merupakan komponen penting dalam proses pembelajaran dan perkembangan siswa. Dengan adannya feedback, siswa dapat mengetahui sejauh mana pencapaian kompetensi pembelajaran yang dikuasainya dan mengevaluasi proses pembelajaran yang dilalui.

Willey dan Gardner (2007) menyatakan bahwa penilaian diri dan teman sejawat 
berpengaruh positif terhadap hasil belajar siswa, yaitu dapat meningkatkan hasil belajar dan meningkatkan hasrat mereka untuk belajar serta dapat mefasilitasi siswa dalam menerima feed back yang menguntungkan dari teman kelompok, sebagai penentu keberhasilan dalam proses pembelajaran.Oleh karena itu, self assessment dan peer assessment dapat mendorong siswa untuk mandiri dan meningkatkan motivasi mereka. Keunggulan dari self dan peerassessment yaitu dapat memonitor, memotivasi kemajuan belajar baik oleh dosen maupun siswa dan meningkatkan proses elaborasi antar siswa dan dosen.

Selain memiliki kelebihan self dan peerassessment memiliki beberapa kelemahan, menurut kalangan masih banyak pengajar yang khawatir bahwa pembelajar akan melakukan ketidakjujuran sehingga penilaian yang mereka lakukan hanya untuk keuntungan mereka sendiri sehingga melakukan penilaian yang bersifat overestimate atau sebaliknya pembelajar akan enggan melakukan penilaian yang sebenarnya sehingga mereka menilai diri mereka jauh di bawah kemampuan mereka yang sebenarnya atau disebut dengan underestimate. Sedangkan penerapan metode peer assessment terdapat beberapa kelemahan antara lain : 1) Siswa kurang mampu menilai rekannya; 2) hubungan persahabatan, perasaan tidak suka dan lain-lain mungkin akan mempengaruhi penilaian; 3) Siswa mungkin tidak suka dinilai oleh rekannya, karena kemungkinan ada diskriminasi, kesalahpahaman dan lain lain.

Dari hasil penelitian kelompok kombinasi penerapan self dan peer assessment dalam pembelajaran mengalami kenaikan kompetensi yang paling tinggi dibanding kelompok self assessment dan peer assessment. Penerapan self dan peer assessment sebagai salah satu metode pembelajaran di skills lab bertujuan agar mahasiswa dapat lebih aktif dalam proses belajar dan dapat meningkatkan kemampuan mahasiswa. Self dan peer assessmentsebagai penilaian formatif memberikan umpan baliksehingga dapat membantu mahasiswa dalam mengidentifikasi kekurangan danmemperbaikinya selama kegiatan pembelajaran berlangsung.

Self dan peer assessment membantu mahasiswa dalam mempelajari dan memahami materi serta menentukan kebutuhan belajarnya. Self dan peer assessment dapat memfasilitasi mahasiswa untuk belajar melalui proses diskusi dengan teman saat melakukan penilaian, sehingga mahasiswa dapat mengetahui 
persepsi teman-temannya mengenai materi yang dipelajari. Secara psikologis, mahasiswa lebih merasa tidak terbebani saat akan dinilai oleh temannya dibandingkan dengan bila dinilai oleh dosen. Mahasiswa cenderung tidak menginginkan dosen yang mengajarkan semua materi dan mengobservasi seluruh kegiatan belajar, sehingga dengan adanya penerapan metode kombinasi self dan peer assessment dalam pembelajaran mahasiswa menjadi lebih menikmati dan bisa lebih santai dalam berlatih mempraktekkan keterampilan.

Penerapan metode self danpeer assessment dinilai dari pendekatan belajar menjadikan kombinasi metode pembelajaran yang saling melengkapi satu sama lain. Mahasiswa pada kelompok yang melakukan self assessment, menggunakan pendekatan belajar mendalam (deeplearning), yaitu mempelajari materi karena tertarik dan merasa membutuhkan. Oleh karena itu, gaya belajarnya cenderung lebih serius dan merusaha memahami materi secara mendalamserta lebih memahamibagaimana cara untuk mempraktekkan dan mengaplikasikannya. Hal ini dapat terjadikarena teknik self assessment mempromosikan orientasi penguasaan tujuan, di mana yang menjadi fokusnya adalah pada peningkatan pengetahuan, pemahaman, dan keterampilan. Sebaliknya, pada mahasiswa yang melakukan peer assessment, menggunakan pendekatan belajar bentuk surface (permukaan) yaitu belajar karena adanya dorongan dari luar (ekstrinsik) sepertituntutan sebagai assess untuk menilai keterampilan teman.

Penerapan metode kombinasiself dan peer assessment merupakan salah satu metode terbaikdalam proses pembelajaran yang dapat diterapkan untuk menciptakan lingkungan belajar yang aktif. Dimana siswa menilai diri sendiri dan menilai hasil belajar teman atau pelajar lainnya serta memberikan umpan balik (feed back) dalam kegiatan pembelajaran. Banyak bukti penelitian penerapan self dan peer assessment memberikan feed back sehingga mendukung proses pembelajaran. Hansen (2015) menyatakan bahwaumpan balik yang di berikan oleh siswa lain bermanfaat dalam proses pembelajaran. Selain itu, pemberian feedback merangsang timbulnya diskusi kelompok yang menjadi sumber daya penting untuk siswa membahas umpan balik.

Penerapan metodekombinasi selfdan peer assessment dalam pembelajaran secara 
signifikan meningkatkan prestasi

akademik, memfasilitasi keterlibatan mendalam dan konstruktif dengan pembelajaran serta memupuk kepercayaan siswa terhadap penggunaan pemikiran kritis dan pengambilan keputusan. Self dan peer assessment dalam pembelajaran menunjukkan bahwa terjadi interaksi teman sebaya dalam belajar, antara siswa dengan siswa, dapat memfasilitasi sikap yang diperlukan untuk menerapkan perubahan dalam rutinitas pembelajaran, sehingga menghadirkan proses pembelajaran yang inovatif. Menurut penelitian Stan (2015) penerapan self dan peer assessment dalam pembelajaran meningkatkan keinginan siswa untuk menilai teman dan memiliki dampak positif pada pembelajaran dalam rangka pencapaian tujuan belajar. Penerapan metode self dan peer assessment dalam pembelajaran menunjukkan peningkatan kesiapan siswa dalam proses pembelajaran.

Dari hasil meta analisis penerapan metode self dan peer assessment dapat memberi dampak positif terhadap perkembangan kepribadian seseorang, antara lain: dapat menumbuhkan rasa percaya diri seseorang, karena dia diberi kepercayaan untuk menilai dirinya sendiri maupun orang lain; menyadari kekuatan dan kelemahan dirinya, karena ketika dia melakukan penilaian kepada orang lain, terlebih dahulu harus melakukan introspeksi/dapat menilai kekuatan dan kelemahan dirinya terlebih dahulu; dapat mendorong membiasakan dan melatih diri untuk berbuat jujur, karena kita dituntut untuk jujur dan objektif dalam melakukan penilaian. Jadi penerapan metode kombinasi self dan peer assessment sangat memungkinkan untuk diaplikasikan dalam proses pembelajaran di laboratorium keterampilan klinik yang dapat memberikan pengaruh yang bermakna terhadap kompetensi mahasiswa D III Kebidanan.

\section{KESIMPULAN}

Penerapan metode kombinasi self dan peer assessment dapat memberikan pengaruh yang bermakna terhadap kompetensi mahasiswa D III Kebidanan.

\section{UCAPAN TERIMA KASIH}

Kepada Direktur dan mahasiswa Akademi Kebidanan Graha Husada Cirebon dan seluruh pihak yang terlibat dan mendukung terlaksananya penelitian ini.

\section{REFERENSI}

Alias EA. (2015)Self, Peer and Teacher Assessments in Problem Based Learning: Are They in Agreements?.Malaysia: Jurnal Procedia - Social and 
Behavioral Sciences. Elsevier Ltd. 204 hal. $309-317$.

Anne C, Nofziger M, Elizabeth $\mathrm{H}$, Naumburg M, Barbara J, Davis, et al.(2010)Impact of Peer Assessment on the Professional Development of Medical Students: A Qualitative Study. Academic Medicine;85(1)

Badan Penelitian Dan Pengembangan. Riset Kesehatan Dasar Tahun 2013

Bostock. (2000) StudentPeerAssessment. The Higher Education Academy Keele University.

Departemen Kesehatan RI. (2009) Standar Proses Pembelajaran Pendidikan Tenaga Kesehatan. BPPSDMK.

Dornan et all. (2011)Medical education theory and practice. Ontario: Churchill Livingstone Elsevier.

Ikatan Bidan Indonesia, Asosiasi Pendidikan Kesehatan Indonesia. (2012) Standar Nasional Pendidikan Kebidanan.

Kartono. (2011) Efektifitas penilaian diri dan teman sejawat untuk penilaian formatif dan sumatif pada pembelajaran mata kuliah analisis kompleks. Jurusan Matematika FMIPA UNNES.

Keputusan Mentri Kesehatan Republik Indonesia Nomor 368/Menkes/SK/III/2007 Tentang Standar Profesi Bidan. (2007)

Kementrian Kesehatan Republik Indonesia. Profil Kesehatan Indonesia Tahun 2016 (2017). Jakarta.

Kiliq, Dogan E. (2007) Measure for university student' Attitude towardspeerassessment Sanliurfa: Harran University.

Liu NF, Carless D.(2006)Peer Feedback: the learning element of peer assessment. Teaching in Higher Education; $\mathrm{Vol}$ 11; 279-290

McMillan JH, Hearn J. (2008) Student selfassessment. The key to stronger student motivation and higher achievement. J Educational horizons ;87: hlm 40.

Mohammad I. (2012) Pengembangan asesmen diri siswa (Student SelfAssessment). Konferensi Ilmiah Nasional.

Orsmond P. (2004) Self-and peerassessmentguidance on practice in t.he biosciences. The Higher Education Academy.

Rochmiyati. (2013)Peer Assessment Model On Collaborative Elaboration Learning For Interdisciplinary Social Studies InThe Junior High Schools.J Penelitian dan evaluasi pendidikan;333;46

Ross JA. (2006)The reliability, validity, and utility of self assessment. J PARE.

Sally A. (2005)How Effective IsSelf Assessment in Writing? In P. Davidson, C. Coombe, W. Jones (Eds.), Assessment in The Arab World. (pp.307-321). United Arab Emirates: TESOL Arabia.

Soisangwarn EA. (2014) Promoting the Reflective Teacher through Peer Coaching to Improve Teaching Skills. Jurnal Procedia - Social and Behavioral Sciences.

Suryadi E. (2008) Pendidikan Laboratorium Keterampilan Klinik. Fakultas Kedokteran Universitas Gajah Mada. Yogyakarta.

Taras M. (2002)Using Assessment for learning and learning from assessment. Assessment \&Evaluation in Higher Education ;6:27

Topping K. (1998) Peer Assessment Between Students in Colleges and Universities. Refiew of Education Research; Vol68; 249267

Valcke M. (1999)Self- and peer- assessment within the context of innovation in assessment \& evaluation. European J of Open, Distance and E-Learning.

Willey K, Gardner AP.(2007)The effectiveness of using self and peer assessment in short courses: Does it improve learning? Proceeding of conference. 
Zulharman. (2009)Self dan peer assessment sumatif. sebagai penilaian formatif dan 